African Journal of Biomedical Research, Vol. 10 (2007); 189 - 192

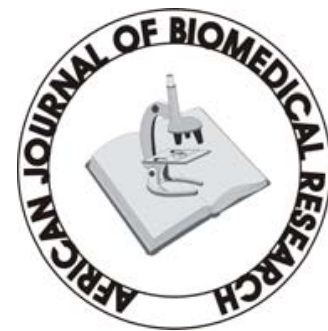

Full-text available at http://www.ajbrui.com http://www.bioline.br/md http://www.ajol.com

Received:

December 2006

Accepted (Revised): March 2007

Published May 2007
Short communication

\section{Interference of Infectious Bursal Diseases (IBD) Virus and Vaccine with the Immune Responses of Guinea Fowls to Newcastle Disease Lasota Vaccination}

\author{
*El-Yuguda A. D, Wachida N and Baba S. S. \\ Animal virus research laboratory, \\ Department of Veterinary Microbiology and Parasitology \\ University of Maiduguri, Nigeria
}

\begin{abstract}
The interference of Infectious bursal disease (IBD) virus and vaccine with the immune response of the grey brested guinea fowl (Numida meleagridis galeata palas) to Newcastle desease (ND) "LaSota" vaccine was studied using hemagglutination inhibition (HI) test for detection of ND virus antibody and agar gel precipitation test (AGPT) for the presence of IBD virus antibody. A statistically significant difference $(\mathrm{p}<0.05)$ in $\mathrm{HI}$ antibody response was noted between the group vaccinated with ND "LaSota" vaccine alone and those infected with IBD virus or vaccinated with IBD vaccine and later vaccinated with ND "LaSota". The Newcastle disease "LaSota" vaccinated group showed highest Geometric Mean Titre (GMT) of HI antibody response of 80 while the IBD virus infected and IBD vaccinated group gave 32 and 19 respectively. Expectedly the IBD infected or vaccinated groups seroconverted to the IBD infection or vaccination. It is concluded that IBD virus or vaccine interfered with the immune response of the guinea fowls to ND "LaSota" vaccine.
\end{abstract}

(Afr. J. Biomed. Res. 10: 189-192)

Keywords: Infectious bursal disease, Newcastle disease LaSota vaccine, guinea fowls, immune response.

*Address for Correspondence (e-mail): elyuguda2000@yahoo.com

Abstracted by:

African Index Medicus (WHO), CAB Abstracts, Index Copernicus, Global Health Abstracts, Asian Science Index, Index Veterinarius, Bioline International , African Journals online 


\section{INTRODUCTION}

Village or rural poultry production means the small scale extensive method of poultry farming carried out in the developing countries of the world. Birds are maintained under scavenging system usually with little or no input for housing, or veterinary care (Cumming, 1990). The village poultry comprises of chickens, guinea fowls, ducks, turkeys, pigeons, geese, ostriches, quails and peacocks (Blackheart, 1990; Sonaiya et al., 1999). Not only are the village poultry most numerous poultry population in the world, they also play a very important role in the cash flow of the rural population (Cumming, 1992). Newcastle disease (ND) and infectious bursal disease (IBD) have remained the two most important infectious disease conditions that are threatening the village chicken and commercial poultry production in most parts of the world (Agoha et al., 1992; Sonaiya et al., 1999; Permin and Pederson, 2002). The epidemiological patterns of ND and IBD are usually influenced by some factors such as wide host range, thermostabillity and variation in strains of the causative viruses. Because of the village poultry setting where chickens and other birds like the guinea fowls are raised together feeding and roosting in the same place, they could serve as source of infection to each other (Soniaya, 1999). Besides the immunosuppressive effects of IBD has been well documented (Lukert, 1992; Trautwein, 1992; ElYuguda, 2000). This paper describes the interference of IBD virus or vaccine with the immune response of guinea fowls to Newcastle disease "LaSota" vaccine.

\section{MATERIALS AND METHODS}

Experimental birds: One hundred guinea fowl growers aged 8 -to-10 week were obtained from local market in Maiduguri, Nigeria. The bids were housed in a large cage and their wings were clipped to prevent them from flying. They were fed growers mash (Sanders feed, Nigeria) along with millet supplementation and were given water ad libitum. They were given antistress medication $\left(\right.$ Vitalit $\left.^{\circledR}\right)$ in drinking water for five days.
Vaccine: Newcastle disease (ND) "LaSota" and infectious bursal disease (IBD) vaccines batch numbers 4/2001 and 7/2001 respectively, used in the vaccination of the experimental birds were obtained from National Veterinary Research Institute ( NVRI) Vom, Nigeria

Challenge virus and test antigens: The IBD virus $\left(\mathrm{EID}_{50} 10^{5}\right)$ used for the challenge study was obtained from NVRI Vom, Nigeria while the IBD virus antigen used in the agar gel precipitation test (AGPT) was macerated bursa of an IBD virus infected 5 weeks old chicks, prepared in the virology laboratory of the department of Veterinary Microbiology and Parasitology of the University of Maiduguri. The antigen used for the hemagglutination inhibition (HI) test was ND "LaSota" Vaccine batch number 10/2002 obtained from NVRI Vom, Nigeria. Positive and negative control sera against each of the two viruses were also obtained from NVRI Vom, Nigeria.

Experimental procedure: The experimental guinea fowls were divided into 4 equal groups (A-to-D) of 25 guinea fowls each. The birds in group A were vaccinated with ND "LaSota” vaccine only, group B birds were infected with IBD virus, group $C$ birds were vaccinated with IBD vaccine and group $D$ were left as control. Seven days after the vaccination or infection, the birds in groups $\mathrm{A}$-to- $\mathrm{C}$ were all vaccinated with ND "LaSota" vaccine. The experimental birds were bled on days $0,7,14,12$, 28,42 and 56 post the initial vaccination with ND or IBD vaccines or infection with IBD virus.

Serum sampling: The birds were bled with sterile syringes and needles through the wing veins into sterile vacutainer tubes. The blood samples were allowed to clot at room temperature and the sera separated by centrifuging at $1,500 \mathrm{rpm}$ for 10 minutes. The sera were then stored in sterile Nunc tubes at $-20^{\circ} \mathrm{C}$ until tested. The test sera were heat inactivated at $56^{\circ} \mathrm{C}$ for 30 minutes and hemadsorbed with $50 \%$ chicken red blood cells to remove non specific agglutinins. The samples were tested for ND virus $\mathrm{HI}$ antibodies and IBD virus precipitin antibodies essentially using the methods of Allan 
and Gough (1974) and Hirai et al. (1972).

Statistical analysis: The significance of difference between the GMTs was calculated by the Student ttest at $\mathrm{P}<0.05$ level of significance.

\section{RESULTS}

The results of the study of the interference of IBD virus or on the immune response of guinea fowls to ND La sota vaccine is presented in table 1 . The ND "LaSota" only vaccinated group (group A) gave highest geometric mean HI antibody titre of 80, while the IBD virus infected or vaccinated group and revaccinated with ND "LaSota" vaccine after one week (groups B and C ) had 35 and 19 respectively. Statistically significant $(\mathrm{p}<0.05)$ difference was observed between the HI antibody response of the birds in group A with either of the other two groups (B and C). The groups B and C birds infected or vaccinated with IBD virus or vaccine respectively seroconverted, with no apparent clinical signs or pathological lesions observed.

\section{Table 1:}

The geometric mean titre (GMT) of HI antibody response of guinea fowls to ND LaSota vaccine following ND LaSota or IBD virus infection or IBD vaccination

\begin{tabular}{llllllll}
\hline Group & \multicolumn{6}{c}{ GMT values of ND HI antibodies days post } \\
& \multicolumn{7}{c}{$\mathbf{2}^{\text {nd }}$ LaSota vaccination) } \\
\cline { 2 - 8 } & $(0)$ & () & $(14)$ & $(21)$ & $(28)$ & $(42)$ & $(56)$ \\
\hline A & $-{ }^{*}$ & 10 & 27 & 80 & 50 & 40 & $\mathrm{NT}^{* *}$ \\
\hline B & - & 5 & NT & 35 & 17 & 6 & 6 \\
\hline C & - & 11 & 19 & 17 & 17 & 7 & 5 \\
\hline D & - & - & - & - & - & - & - \\
\hline Keys: & $-*$ & Negative & NT**-not tested &
\end{tabular}

\section{DISCUSSION}

Because of the Village poultry setting, where different species of birds are raised together (Sonaiya et al.,1999; Jugessur and Seenevasssen Pillay, 2002; Ekwe et at., 2002; Khalafalla et al., 2002), feeding and roosting in the same place they serve as source of infection to each other . Of these group of birds is the guinea fowl, which has been reported to be very susceptible to infectious diseases of poultry, such as Newcastle disease, egg group syndrome- 76, infectious bursal disease, etc (Agoha et al., 1992 ). Guinea fowls rank second to chickens in terms of population and acceptability to farmers in Nigeria (Nawathe and Lamorde, 1982). It is observed in this study that IBD virus infection or vaccination reduces the response of guinea fowls to ND "LaSota" vaccine. This agrees with the findings of other workers (Rao and Rao, 1992; El- Yuguda, 2000) who observed significant depression of primary antibody of chickens to ND vaccine when administered one week after IBD infection or vaccination. Trautwein (1992) also reported that chickens infected with IBD virus become susceptible to opportunistic secondary infections and respond poorly to immunization against other pathogens. This could be due to the effect of the virus on the lymphoid organs, such as the bursa of Fabricious of the infected birds. The virus causes necrosis of the lymphocytes in the medullary area of the lymphoid organs resulting in the suppression of both humoral and cell mediated immune responses (Ritter, 1982; Fenner et al.,1986; Lukert, 1992 ). The poor response of the IBD virus infected or IBD vaccinated guinea fowls to ND "LaSota" vaccine and their seroconversion to the IBD virus with no apparent clinical signs observed in this study shows that the guinea fowls could serve as source of IBD virus infection to chickens and other birds. This is because serological evidence has shown that free flying feral birds serve as source of spread of ND and other viruses to chickens, even when they do not come down with the clinical disease (Martin 1992). This may hamper the success of the ND control program in the village poultry (Spradbrow, 1987; Martin, 1992)

It is therefore important that IBD in the village chickens be controlled not only for the sake of the village chickens alone, but to enhance the success of the ND control program and to avoid the creation of an IBD virus reservoir hosts among other village poultry species. It's observed in this study that although the guinea fowls do not come down with IBD, but because of the seroconversion to the IBD virus and subsequent poor response to ND "LaSota" vaccination observed, the guinea fowls could serve as reservoir host for the virus.

\section{Acknowledgement}

The authors wish to acknowledge the technical assistance of Ms 
Awa A. Dzikwi and Mr Andrew Ali both of the animal virus research lab., Department of Veterinary Microbiology and Parasitology University of Maiduguri Nigeria

\section{REFERENCES}

Agoha N.J., Akpavie S. 0. and Durojaiye O. F. (1992). Pathogenecity of two strains of Newcastle disease virus in the grey - breasted helmet guinea fowl. Vet. quarterly, 14(2):51-53.

Allan W. H. and Gough R. F. A. (1974). Standard haemagglutination test for Newcastle

Disease: Comparison of the macro and micro methods. Vet .Rec. 95:120-123.

Branckaert R. (1990). Le role des volailles non conventionalles dans I'aviculture Africaine. In: CTA Seminar proceeding on smallholder rural poultry production. Thessaloniki, Greece 9-13 Oct. 1990 Pp 61.

Cumming R. B. (1992). Village chicken production : problems and prospects. In: P. B. Spradbow (Ed.) Newcastle disease in Vilage poultry (Control with thermostable oral vaccine). Proceeding of an international workshop held in Kuala Lumpur, Malaysia, 6-10 Oct. 1991. ACIAR monograph No.39 Pp12-24.

Ekwe F. N., Pone K. D., Mafeni M. J., Nfi A. N. and Njoya J. (2002). Survey of the traditional poultry production system in the Bamend area Cameroon.In Characteristic and parameters of family puoultry production in Africa FAO/ IAEA pub. Pp15-64.

El-Yuguda A. D. (2000). Effects of material antibodies and vaccine interactions on specific antibody response of Village chickens to single or combined Newcastle disease and infectious bursal disease vaccines. M.V.Sc. dissertation, University of Maiduguri, Nigeria.

Hirai k., Shimakura S. and Herose M. (1972). Immunodiffution to infectious bursal disease. Avian Dis 16:61-64

Jugessur V. S. and Seenevassen Pillay M. M. (2002). Family poultry production in Mauritius: Problems and prospects. In: Characteristics and parameters of Village poultry production in Afirca. FAO/AEA pub. Pp 65-71. Khalafalla A. I.; Awad S. and Hass W. (2002). Village poultry production in the Sudan.

In: Characteristics and parameters of Village poultry production in Africa FAO/ IAEA pub. Pp 87-94.
Lukert P. D. (1992). Infectious bursal disease. In: A. E. Castro and W. P. Heuschelle (Ed) Veterinary diagnostic virology: a practitioners guide Mosby year book publishers Missouri Pp35-36.

Martin P. A. J. (1992). The epidemiology of Newcastle disease in Village chickens. In: Newcastle Disease in Village chicken (control with thermostable oral vaccine). Proceedings of an International workshop held in Kuala Lumpur, Malaysia, 6-10 Oct. 1991. ACIAR Monograph No. 36 Pp 40-45.

Nawathe D. R. and Lamorde A.G.(1982). Gumboro disease: problems of its control in Nigeria. Rev. Tech. off. Int. Epiz. 1:1163-1168.

Njue S. W., Kosiiti J. I., Macharia M. J., Gacheru .G. and Mbugua H.C.W. (2002). Health and management improvement of family poultry production in Africa. FAO/IAEA Pub. Pp39p46.

Permin A. and Pederson G. (2002). The need for a holistic view on disease problems in free range Chickens. In: characteristics and parameters of family poultry production in Africa. FAO/IAEA Pub Pp1-8.

Rao V. N. and Rao K. N. P. (1992). Immunodepression to Ranikhet disease vaccination due to Infectious bursal disease virus in chickens. Indian Vet. J. 69(9): 689.

Ritter J. (1982). On vaccination against Gumboro. Poultry International, April 1982.

Pp 68-70.

Sonaiya E. B., Branckaert R. D. S. and Guéye E. F (1999). Research and development options for family poultry. First INFPD/FAO electronic conference on family poultry, Guéye (Ed). http://www.fao.org /ag/aga/agap/lpa.fampol/intropap.htm

Spradbrow P. B. (1987). Newcastle disease-an overview. In: J. W. capland (Ed)

Newcastle disease in poultry (a new food pellet vaccine). ACIAR monograph No. 5. pp12-18.

Trautwein G. (1992). Immune mechanism in pathogenesis of viral disease: a review.

Vet, Microbiol. 33:19-34. 